\title{
Anxiety Levels and Sleep Quality of Individuals During the COVID-19 Outbreak
}

\section{COVID-19 Salgını Sürecinde Bireylerin Anksiyete Düzeyleri ve Uyku Kaliteleri}

\author{
(1) Hülya Kök Eren \\ Eskişehir Osmangazi University Faculty of Health Sciences, Department of Mental Health and Diseases Nursing, Eskişehir, Turkey
}

\begin{abstract}
Objective: This study aimed to investigate the relationship between sleep quality and anxiety levels of individuals in Turkey during the Coronavirus disease-2019 (COVID-19) pandemic.

Materials and Methods: In this cross-sectional study, data were electronically collected between 10 May 2020 and 30 July 2020 . Personal information form, State-trait anxiety inventory and Pittsburg sleep quality index were used as data collection tools.

Results: A statistically significant difference was found in terms of gender, age, educational status, economic status, childbearing status and statetrait anxiety scores. It was determined that 183 (78.9\%) participants with good sleep quality did not have sleep problems after the start of the COVID-19 outbreak, and 113 (65.3\%) participants with poor sleep quality experienced sleep problems after the start of the COVID-19 outbreak. As a result of an increase in the state-strait anxiety scale score by 1 point, the risk of poor sleep quality increased 1.051 times (5.1\%). Conclusion: In this study, the anxiety levels of women, young people, children, individuals with low educational status and individuals with poor economic status were high. After the COVID-19 outbreak started, the number of individuals with sleep problems increased. Increasing anxiety levels during the COVID-19 outbreak increased poor sleep quality. These results will help mental health professionals, who are involved in community mental health services, to manage such individuals in a better way.
\end{abstract}

Keywords: COVID-19, outbreak, anxiety, sleep quality
Öz

Amaç: Koronavirüs hastalı̆̆ı-2019 (COVID-19) pandemi sürecinde Türkiye'deki bireylerde anksiyete düzeyleri ve uyku kaliteleri arasındaki ilişkinin incelenmesi amaçlanmıştır.

Gereç ve Yöntem: Kesitsel tipte olan çalışma, 10 Mayıs-30 Temmuz 2020 tarihleri arasında, elektronik ortamda toplanmıştır. Çalışmaya 405 kişi katılmışıı. Veri toplama araçları kişisel bilgi formu, Durumluluksürekli kaygı envanteri ve Pittsburg uyku kalitesi indeksidir.

Bulgular: Cinsiyet, yaş, eğitim durumu, ekonomik durum, çocuk sahibi olma durumu ile durumluluk-sürekli kaygı puanlarına göre istatistiksel olarak anlamlı fark bulunmuştur. lyi uyku düzeyinde olan 183 kişinin $(\% 78,9)$ COVID-19 sonrası uyku sorunu yaşamadığı, kötü uyku düzeyinde olan 113 kişinin $(\% 65,3)$ COVID-19 sonrası uyku sorunu yaşadığı tespit edilmiştir. Durumluk kaygı ölçeği puanlarının 1 birim artması sonucunda (yani durumluk kaygının atması sonucunda), kötü uyku kalitesi riskinin 1,051 kat daha artacağı (\%5,1 artacağı) tespit edilmiştir.

Sonuç: Çalışmamızda, kadınların, gençlerin, eğitim durumu düşük, ekonomik durumu kötü ve çocuk sahibi olanların anksiyete seviyeleri yüksek bulunmuştur. COVID-19 salgını başlandıktan sonra uyku sorunu yaşayan bireylerin sayısı artmıştır. COVID-19 salgını sürecinde kaygının artması kötü uyku kalitesini artırmıştır. Bu sonuçlar toplum ruh sağlığı hizmetlerinde ruh sağlığı çalışanlarına ışık tutacaktır.

Anahtar Kelimeler: COVID-19, salgın, anksiyete, uyku kalitesi

\section{Introduction}

Anxiety levels of people inevitably increase due to the sudden nature and contagiousness of the epidemic. The world is panicstricken due to the new Coronavirus disease-2019 (COVID-19) pandemic. Causes such as the rapid spread of the virus, deaths due to the virus, lack of sufficient information on treatment, social isolation, disruption of daily routine and uncertainties increased anxiety in humans (1-4). A survey involving 1.210 people in China, the origin of the virus, suggests that $54 \%$ of the participants show symptoms moderate or severe anxiety and $29 \%$ of the participants show symptoms of medium to severe anxiety due to the COVID-19 outbreak (5). In their study, Yin et al. (6) stated that the level of anxiety increased by $15 \%$ during the course of the corona virus pandemic. In their study conducted in twenty five countries in March, Limcaoco et al. (7) 
found that the COVID-19 outbreak increased anxiety symptoms of individuals.

Another important negative effect of the outbreak is impairment of sleep quality (8). Sleep quality, consisting of components such as sleep delay, sleep duration, habitual sleep efficacy, sleep disorders, use of sleeping medication and daytime dysfunction, expresses the individual's sleep efficiency (9). Sleep quality is deteriorated by social isolation and disruption of daily routines during the course of the pandemic. Besides, sleep quality is also negatively affected by anxiety $(4,10)$. Studies suggest that anxiety is one of the important conditions that worsen sleep quality (11-13). It is thought that stress and anxiety of people will negatively affect their sleep quality due to COVID19 pandemic $(4,10)$. Therefore, this study aimed to investigate the relationship between anxiety level and sleep quality of individuals during the COVID-19 pandemic.

\section{Materials and Methods}

This cross-sectional study aimed to investigate the relationship between anxiety level and sleep quality of individuals in Turkey during the course of the COVID-19 pandemic. The study conducted involved individuals age 18 or above living in Turkey. Snowball sampling method was used in sampling. For the snowball sampling method, one of the units in the universe is reached in any way. Then, with the help of the contacted person, another person is contacted and then another person is contacted in the same way. Thus, the sample is enlarged in the form of a snowball effect (14). To calculate the number of samples, the sample calculation formula with known universe was used. The required sample size was calculated as 384 with $95 \%$ confidenceinterval and $\pm 5 \%$ sampling error for the study. However, morepeople should be sampled to compare the subgroups. Since it was not possible to meet with the public face-to-face due to the pandemic situation, the questions were prepared in Google form, and people were invited electronically (e-mail, WhatsApp, Facebook, Instagram). People were informed about the study with the informed consent form before answering the questions. The data were collected between 10.05.2020 and 30.07.2020. 450 people were invited to the study, 405 (90\%) people participated in the study.

\section{Data Collection Tools}

The data collection tools included "personal information form", "state-trait anxiety inventory" and "Pittsburg sleep quality index (PSQI)".

Personal information form: The personal information form, which was developed in line with the study, consists of nine questions. These questions are related to gender, age, education, marital and economic status, having children, whether or not to be diagnosed with COVID-19, having a psychiatric disease and sleep problems.

State-trait anxiety inventory: The Likert-type scale, developed by Spielberg et al., consists of 40 items, 20 of which are for measuring the state anxiety and 20 of which are for measuring the trait anxiety. The scale has been translated into Turkish by Öner and Le Compte (15) in 1977 and was used with adaptations to assess anxiety levels. State anxiety scale describe how he feels at once and under certain conditions, taking into account their feelings about the situation they are in from answering; The trait anxiety scale is how the individual usually feels it requires description. Both scales are made of twenty items. The scale is a 4-point Likert type: "none", "a little", "a lot", "completely". The total scores obtained from both scales are individually evaluated. Cronbach's Alpha was found between 0.94-0.96 for state anxiety scale and 0.83-0.87 for trait anxiety scale. In this study, Cronbach's Alpha value was found as 0.93 for state anxiety scale and 0.88 for trait anxiety scale (15).

PSQI (Pittsburg Sleep Quality Index): To evaluate sleep quality, this study will use the PSQI, which is a self-report scale. The scale was developed by Buysse et al. (9) in 1989, and its validity and reliability study was performed by Ağargün et al. (16) in 1996. Cronbach's Alpha value of the scale was reported as 0.80 . Cronbach's Alpha in the present study was 0.84. PSQI consists of 7 components: subjective sleep quality, sleep latency, sleep duration, habitual sleep efficiency, sleep disturbance, use of sleep medication and daytime dysfunction. Each of the multiple-choice questions is scored from 0 to 3 by individuals. The sum of the seven component points gives the total PSQI score. The total score obtained from this index ranges from 0 to 21 , and those scoring above 5 are considered to have "bad sleep quality" and those scoring 5 or below are considered to have "good sleep quality" (16).

Ethics: Permission was obtained for the study from Eskişehir Osmangazi University Social and Human Sciences Research and Publication Ethics Committee on 05.05.2020 (2020-9) and from Turkish Ministry of Health on 06.05.2020.

\section{Statistical Analysis}

Frequency tables and descriptive statistics were used for interpretation of the results. In the case of data with normal distribution, "independent Sample t-test" (t-table value) were used to compare the measurement values of the two independent groups; and "ANOVA" test (F-table value) statistics were used to compare three or more independent groups. In the data without normal distribution, "Mann-Whitney U test" (Z-table value) was used to compare the measured values of two independent groups; and "Kruskal-Wallis $\mathrm{H}^{\text {" }}$ ( $\chi^{2}$-table value) statistics were used to compare three or more independent

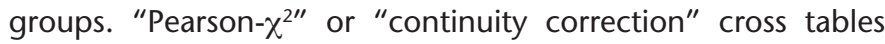
were used in the analysis of the relationship of two qualitative variables according to the expected value levels. Binary logistic regression: Backward LR model was used to analyze variables that affect PSQI classes.

\section{Results}

$67.9 \%$ (275) of the individuals participating in the study were women, and $34.6 \%$ (281) were under 20 years old. $68.4 \%$ (277) of the individuals are university graduates and high graduate, $67.2 \%(272)$ are single, $28.6 \%(116)$ have children. Of the individuals in the study, $69.9 \%$ (283) had a moderate 
economic level (equal income and expense level), 4.4\% (18) had a psychiatric illness, and $7.7 \%$ (31) had a diagnosis of COVID-19 either in themselves or in their family. While $23 \%$ (93) of the participants had sleep problems before the COVID19 outbreak, 40\% (162) had sleep problems after the COVID19 outbreak.

State anxiety scale of individuals was found to be $41.53 \pm 11.07$, and the average trait anxiety was found to be $43.61 \pm 8.68$. A statistically significant difference was found in terms of state anxiety scale on the basis of genders $(t=4.288, p=0.000)$. The state anxiety scale scores of females were statistically significantly higher compared to males. A statistically significant difference was found in terms of state anxiety scale scores by age categories $(F=3.067, p=0.028)$. A statistically significant difference was found between the age group 21-30 and those over 40 . The state anxiety scale scores of those in the 21-30 age group were statistically significantly higher compared to those over the age of 40 . A statistically significant difference was found in terms of trait anxiety scale scores on the basis of marital status $(Z=-3.387, p=0.001)$. The trait anxiety scale scores of the singles were statistically significantly higher than the score of the married people. A statistically significant difference was found in terms of state anxiety scale scores on the basis of the presence of children $(t=2.029, p=0.043)$. The state anxiety scale scores of those without children were statistically significantly higher compared to those with children (Table 1).

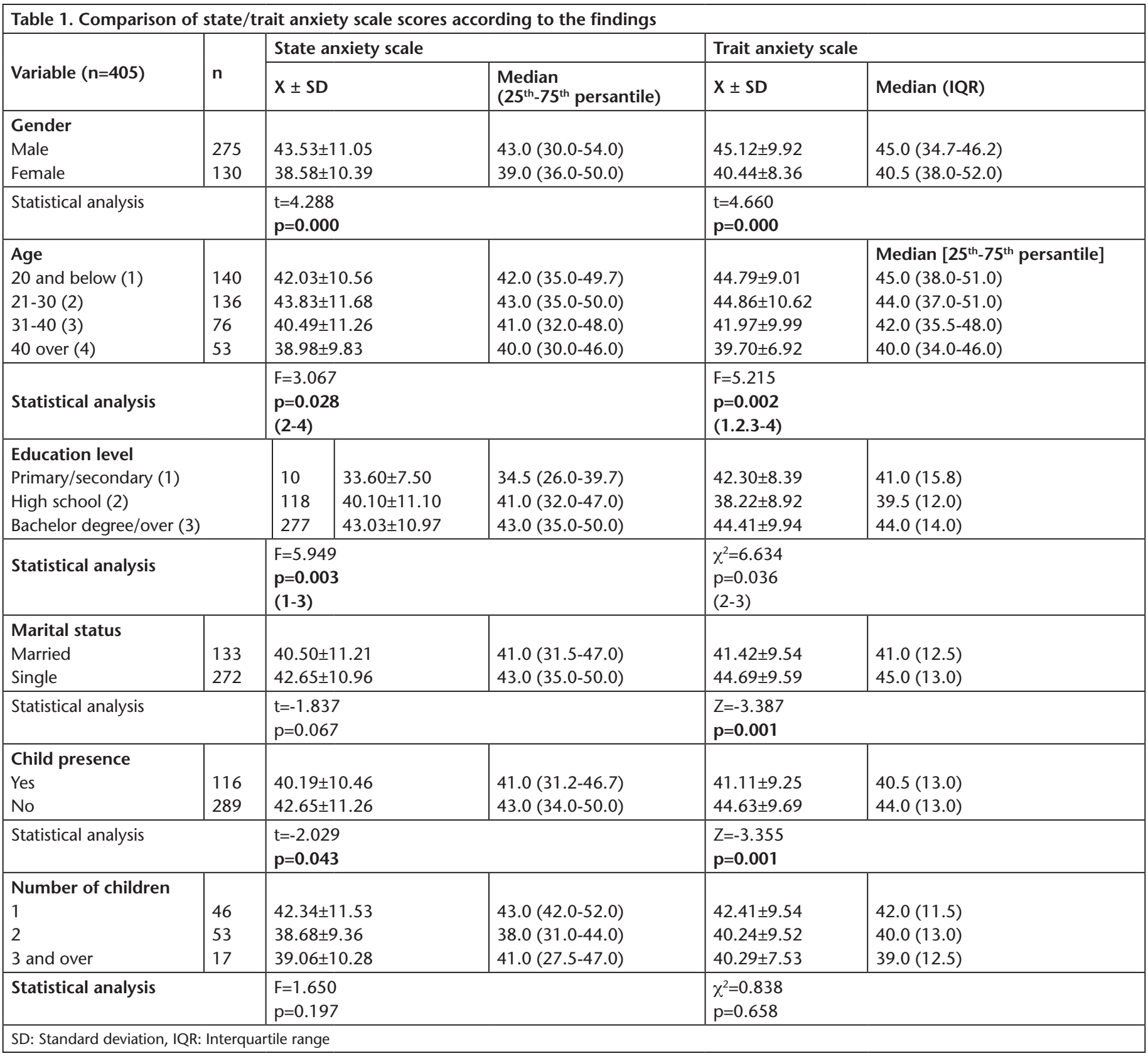


A statistically significant difference was found in terms of state anxiety scale scores on the basis of economic levels $(F=9.087, p=0.000)$. A statistically significant difference was found between those with poor economic level and those with medium or good economic level. The state anxiety scale scores of those with poor economic level are statistically significantly higher compared to those with medium or good economic level. A statistically significant difference was found in terms of state anxiety scale scores on the basis of having sleep problems before COVID-19 $(t=4.031, p=0.000)$. The state anxiety scale scores of those who had sleep problems before COVID-19 were statistically significantly higher compared to those who did not have pre-COVID sleep problems. A statistically significant difference was found in terms of trait anxiety scale score on the basis of having sleep problems before COVID-19 ( $Z=-$ $3.739, p=0.000)$. Trait anxiety scale scores of those who had sleep problems before COVID-19 were statistically significantly higher compared to those who did not have pre-COVID sleep problems (Table 2).

A statistically significant difference was found in terms of state anxiety scale scores according to the state of having sleep problems after COVID-19 ( $t=8.266, \mathrm{p}=0.000)$. The state anxiety scale scores of those who had sleep problems after COVID-19 were statistically significantly higher compared to those who did not have sleep problems after COVID-19. A statistically significant difference was found in terms of trait anxiety scale scores on the basis of having sleep problems after COVID-19 $(Z=-5.914, p=0.000)$. The trait anxiety scale scores of those who had sleep problems after COVID-19 were statistically significantly higher compared to those who did not have sleep problems after COVID-19 (Table 2).

A statistically significant relationship was found between PSQI classes and psychiatric diagnosis status $\left(\chi^{2}=4.416, \mathrm{p}=0.036\right)$. It was found that 226 people (97.4\%) with good sleep level had no psychiatric diagnosis, and 12 people $(6.9 \%)$ with bad sleep level had psychiatric diagnosis. It was found that those with a psychiatric diagnosis have predominantly bad sleep quality, while those without a psychiatric diagnosis have predominantly good sleep quality. A statistically significant relationship was found between PSQI classes and presence of sleep problems before COVID-19 $\left(\chi^{2}=83.561, p=0.000\right)$. It was found that 217 people (93.5\%) with good sleep levels did not have sleep problems before COVID-19, and 78 people $(45.1 \%)$

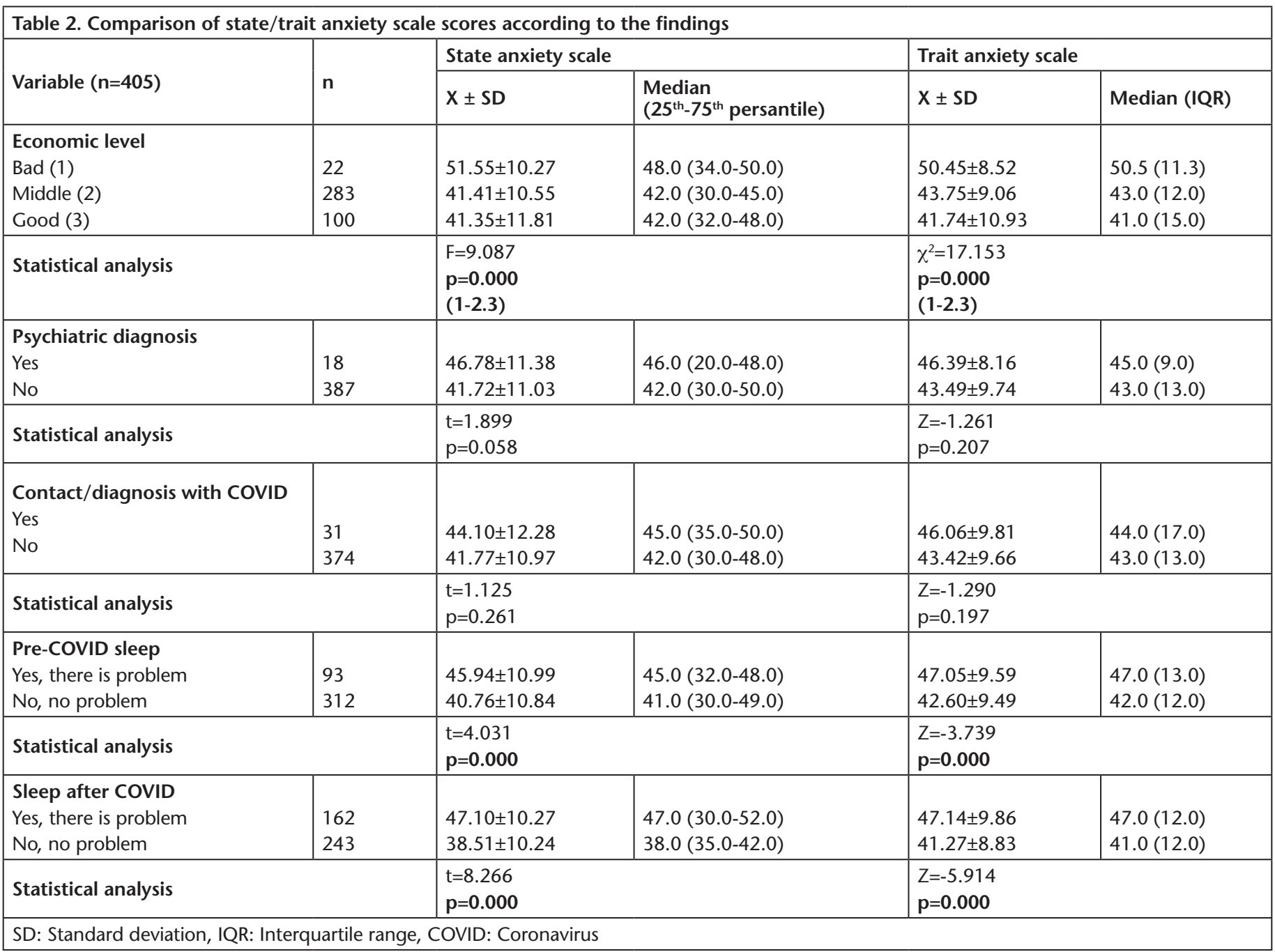


with bad sleep levels had sleep problems before COVID-19. It was found that those who had sleep problems before COVID19 had predominantly poor sleep quality, and those who did not have sleep problems before COVID-19 had predominantly good sleep quality. A statistically significant relationship was found between PSQI classes and presence of sleep problems after COVID-19 $\left(\chi^{2}=80.660, p=0.000\right)$. It was found that 183 people (78.9\%) with good sleep level did not have sleep problems after COVID-19, and 113 people (65.3\%) with bad sleep level experienced sleep problems after COVID-19. It was found that those who had sleep problems after COVID-19 had predominantly poor sleep quality, and those who did not experience sleep problems after COVID-19 had predominantly good sleep quality. According to these two variables, the rate of people who had sleep problems after COVID-19 and who had poor PSQI-class sleep degree increased (Table 3).

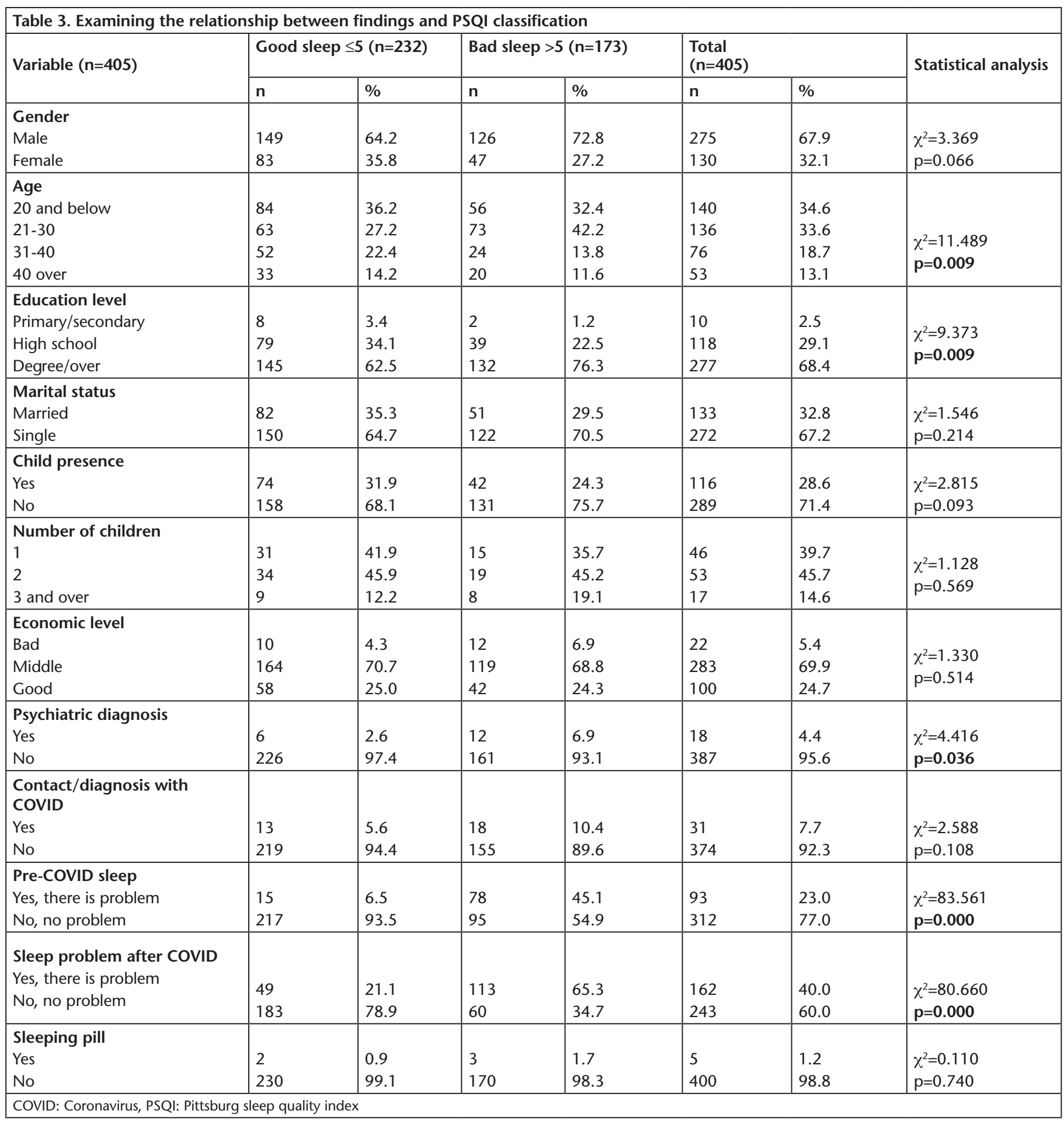


As a result of logistic regression: Backward LR model, which was performed by including the parameters of gender, age, education level, presence of psychiatric diagnosis, presence of sleep problems before and after COVID-19, state and trait anxiety inventory; the variable of sleep problem before and after COVID-19 and state anxiety scale score were used in the optimal model. The model that examines the factors affecting sleep quality found that having sleep problems before COVID19 has a significant effect on PSQI $(p<0.05)$. It was found that those with sleep problems before COVID-19 will have 6.142 times more risk of poor sleep quality compared to those without sleep problems before COVID-19. It was determined that presence of sleep problems after COVID-19 has a significant effect on PSQI $(p<0.05)$. It was found that those with sleep problems after COVID-19 will have 2.460 times more risk of poor sleep quality compared to those without sleep problems after COVID-19. It was found that the state anxiety scale scores have a significant effect on PSQI $(p<0.05)$. It was found that the risk of poor sleep quality will increase 1.051 times $(5.1 \%$ increase) with the increase in the state anxiety scale scores by 1 unit (i.e. as a result of the increase in the state anxiety) (Table 4).

\section{Discussion}

This cross-sectional study aimed to investigate the relationship between anxiety level and sleep quality of individuals in Turkey during the course of the COVID-19 pandemic. In our study, anxiety levels of females were found statistically significantly higher compared to men. In their study, Wang et al. (17) found that females have three times more risk of anxiety compared to males. Anxiety levels of females may be higher compared to men due to their sensitivity about health, responsibilities, and higher exposure to news on the pandemic social media (7,17-19).

According to the results of our study, young people have a higher level of anxiety. Similar results were found in studies conducted during the course of COVID-19 $(7,18)$. Individuals' psychological self-regulation increases as the age increases (17). Moreover, the fact that young people stay at home during the pandemic and that they cannot do what they want, and the uncertainties in the educational process, and the fact that they are constantly dealing with news on the pandemic through social media may have increased their anxiety levels (20).

It was found that those with higher education level had higher anxiety level. In their study, Hu et al. (2) found similar results.
Those with higher education levels are expected to be more aware of the outbreak, which may have increased their level of anxiety for the health of themselves and their family (17). In our study, anxiety levels of those without children were statistically significantly higher compared to those with children. In their study conducted during the COVID-19 pandemic, Shevlin et al. (18) states that having a child or children increases the anxiety. In that study, anxiety level of the individuals may have been found high due to the protective role of parenting. Anxiety levels of those with bad economic level are statistically significantly higher compared to those with medium or good economic level. Poor economic situation is an important risk factor for anxiety $(18,21)$.

In our study, anxiety levels of those who had sleep problems before and/or after COVID-19 were found to be higher compared to those who did not have sleep problems before and/or after COVID. It was found that the risk of poor sleep quality will increase 1.051 times $(5.1 \%$ increase) with an increase in state anxiety by 1 unit (increase of anxiety during the COVID-19 pandemic). Sleep problems may accompany anxiety, or occur due to or as a result of anxieties (12). Pandemic also increases anxiety of individuals $(6,7,22)$. Increased anxiety during the pandemic is a significant risk for poor sleep quality $(4,23,24)$. Anxiety may bring along insomnia or difficulty to fall asleep or keep sleeping (11).

In our study, no statistically significant relationship was found between PSQI classes and gender. Similar results were found in the study of Huang and Zhao (22). Although we generally reported that females have worse sleep quality $(25,26)$, the literatures includes studies reporting that there is no relationship between gender and sleep quality. It is known that sleep quality worsens with age $(26,27)$. In our study, it was found that young individuals have good sleep quality. One of the factors that negatively affect sleep quality is the presence of a psychiatric disease. Poor sleep quality appears as both a cause and a symptom in psychiatric patients $(28,29)$. Our study supports the literature and it was found that those with psychiatric diagnosis have predominantly poor sleep quality, while those without psychiatric diagnosis have predominantly good sleep quality.

Our study found that 183 people (78.9\%) with good sleep level did not have sleep problems after COVID-19, while 113 people (65.3\%) with poor sleep level experienced sleep problems after COVID-19. It was found that those who had sleep problems after COVID-19 had predominantly poor sleep quality, and those who did not experience sleep problems after COVID-19

\begin{tabular}{|c|c|c|c|c|c|c|c|c|}
\hline \multirow{2}{*}{ Variable } & \multirow{2}{*}{ B } & \multirow{2}{*}{ S.H. } & \multirow{2}{*}{ Wald } & \multirow{2}{*}{ SD } & \multirow{2}{*}{$p$} & \multirow{2}{*}{ OR } & \multicolumn{2}{|c|}{$95 \%$ OR } \\
\hline & & & & & & & Lower & Upper \\
\hline Sleep after COVID* & 0.900 & 0.277 & 10.532 & 1 & 0.001 & 2.460 & 1.428 & 4.238 \\
\hline State anxiety & 0.050 & 0.012 & 16.809 & 1 & 0.000 & 1.051 & 1.026 & 1.077 \\
\hline constant & -3.190 & 0.524 & 37.068 & 1 & 0.000 & 0.041 & - & - \\
\hline
\end{tabular}


had predominantly good sleep quality. According to these two variables, the rate of people who have sleep problems after COVID-19 and a poor PSQI-class sleep level increased. A study conducted in Italy during the COVID-19 pandemic found that $57.1 \%$ of individuals have poor sleep quality (24). During the COVID-19 pandemic, the social isolation and the changes in our lives for protection against the virus may have impaired the sleep quality since they have an impact on the sleep time, sleep latency, and bedtime and waking time $(10,30)$.

\section{Conclusion}

Our study found that women, young people, people with low education level, people with poor economic situation and people with children have high levels of anxiety. Having a psychiatric diagnosis adversely affects sleep quality. After onset of the COVID-19 outbreak, the number of individuals experiencing sleep problems increased. It was found that the risk of poor sleep quality will increase 1.051 times $(5.1 \%$ increase) with the increase in the state anxiety scale scores by 1 unit (i.e. as a result of the increase in the anxiety during the COVID-19 pandemic). These results will shed light on mental health professionals in community mental health services. Findings are based on individuals' self-reports. Therefore, the generalizability of the results obtained represents a limitation of this study.

\section{Ethics}

Ethics Committee Approval: Permission was obtained for the study from Eskişehir Osmangazi University Social and Human Sciences Research and Publication Ethics Committee on 05.05.2020 (2020-9) and from Turkish Ministry of Health on 06.05.2020.

Informed Consent: Informed consent was obtained.

Peer-review: Internally peer-reviewed.

Financial Disclosure: The author declared that this study received no financial support.

\section{References}

1. Park SC, Park YC. Mental health care measures in response to the 2019 novel coronavirus outbreak in Korea. Psychiatry Investig 2020;17:85-6.

2. Hu W, Su L, Qiao J, Zhu J, Zhou Y. Countrywide quarantine only mildly increased anxiety level during covid-19 outbreak in china. medRxiv 2020:1-20.

3. Xiang Y, Yang Y, Li W, Zhang L, Zhang Q, Cheung T, Ng C. Timely mental health care for the 2019 novel coronavirus outbreak is urgently needed. Lancet Psychiatry 2020;7:228-9.

4. Xiao H, Zhang Y, Kong D, Li S, Yang N. Social capital and sleep quality in individuals who self-isolated for 14 days during the coronavirus disease 2019 (COVID-19) outbreak in january 2020 in China. Med Sci Monit 2020 Mar 20;26:e923921. doi: 10.12659/MSM.923921

5. Wang C, Pan R, Wan X, Tan Y, Xu L, Ho CS, Ho RC. Immediate psychological responses and associated factors during the initial stage of the 2019 coronavirus disease (covid-19) epidemic among the general population in china. Int J Envir Res Public Health 2020;17:2-25.
6. Yin X, Wang J, Feng J, Chen Z, Jiang N, Wu J, Yan S, Li H, Lv C, Lu $Z$. The impact of the corona virus disease 2019 outbreak on chinese residents' mental health. Available at SSRN 35566802020

7. Limcaoco R, Mateos E, Fernandez J, Roncero C: Anxiety, worry and perceived stress in the world due to the covid-19 pandemic, march 2020. Preliminary results. medRxiv 2020. doi: 10.1101/2020.04.03.20043992

8. Su T, Lien T, Yang C, Su Y, Wang J, Tsai S, Yin J. Prevalence of psychiatric morbidity and psychological adaptation of the nurses in a structured sars caring unit during outbreak: a prospective and periodic assessment study in taiwan. J Psychiatr Res 2007;41:119-30.

9. Buysse D, Reynolds C, Monk T, Berman S, DJ K. The pittsburgh sleep quality index: A new instrument for psychiatric research and practice. Psychiatry Res 1989;28:193-213.

10. Altena E, Baglioni C, Espie C, Ellis J, Gavriloff D, Holzinger B, Schlarb A, Frase L, Jernelöv S, Riemann D. Dealing with sleep problems during home confinement due to the covid-19 outbreak: Practical recommendations from a task force of the european cbt-i academy. J Sleep Res 2020:1-16.

11. Örsal Ö, Kök- Eren H, Duru P. Examination of factors affecting the sleep quality of psychiatry patients using structural equation model. J Psychiatric Nurs 2019;10:55-64.

12. Hacimusalar $Y$, Karaaslan O. Assessment of sleep quality of patients with panic disorder and generalized anxiety disorder during remission: A case-control study. Arch Clin Psychiatr (São Paulo) 2020;47:19-24.

13. Lader M. Sleep and anxiety disorders; synopsis of sleep medicine, Apple Academic Press, New Jersey, 2016:225-36.

14. Kılıç S. Örnekleme yöntemleri. J Mood Disord 2013;3:44-6.

15. Öner N, Le Compe A. Durumluk-sürekli kaygı envanteri el kitabı. İstanbul Boğaziçi Üniversitesi Yayımları, 1987.

16. Ağargün MY, Kara H, Anlar Ö. The validity and reliability of the pittsburgh sleep quality index. Turk Psikiyatri Derg 1996;7:107-15.

17. Wang Y, Di Y, Ye J, Wei W. Study on the public psychological states and its related factors during the outbreak of coronavirus disease 2019 (covid-19) in some regions of china. Psychol Health Med 2020:1-10.

18. Shevlin M, McBride O, Murphy J, Miller J, Hartman T, Levita L, Mason L, Martinez A, McKay R, Stocks T: Anxiety, depression, traumatic stress, and covid-19 related anxiety in the uk general population during the covid-19 pandemic. Psyarxiv 2020. doi: 10.31234/osf.io/ hb6nq Preprint

19. Zhong B, Luo W, Li H, Zhang Q, Liu X, Li W, Li Y. Knowledge, attitudes, and practices towards covid-19 among chinese residents during the rapid rise period of the covid-19 outbreak: a quick online cross-sectional survey. Int J Biol Sci 2020;16:1745.

20. Sahoo S, Rani S, Shah R, Singh AP, Mehra A, Grover S. COVID-19 pandemic-related anxiety in teenagers. Indian J Psychiatry 2020;62:328-30.

21. Ueda M, Stickley A, Sueki H, Matsubayashi T. Mental health status of the general population during the covid-19 pandemic: A cross-sectional national survey in japan. medRxiv 2020. doi: 10.1101/2020.04.28.20082453.

22. Huang Y, Zhao N. Generalized anxiety disorder, depressive symptoms and sleep quality during covid-19 outbreak in China: a web-based cross-sectional survey. Psychiatry Res 2020:112954.

23. Zhang F, Shang Z, Ma H, Jia Y, Sun L, Guo X, Wu L, Sun Z, Zhou Y, Wang $Y$. High risk of infection caused posttraumatic stress symptoms in individuals with poor sleep quality: A study on influence of coronavirus disease (Covid-19) in China. medRxiv 2020. doi: 10.1101/2020.03.22.20034504. 
Hülya Kök Eren.

Anxiety and Sleep During the COVID-19 Outbreak

24. Casagrande M, Favieri F, Tambelli R, Forte G. The enemy who sealed the world: effects quarantine due to the COVID-19 on sleep quality, anxiety, and psychological distress in the Italian population. Sleep Med 2020;75:12-20.

25. Li L, Sheehan C, Thompson M. Measurement invariance and sleep quality differences between men and women in the pittsburgh Sleep Quality Index. J Clin Sleep Med 2019;15:1769-76.

26. Madrid-Valero JJ, Martínez-Selva JM, Ribeiro do Couto B, SánchezRomera JF, Ordoñana JR. Age and gender effects on the prevalence of poor sleep quality in the adult population. Gac Sanit 2017;31:18-22.

27. Ohayon M, Wickwire E, Hirshkowitz M, Albert S, Avidan A, Daly F, Dauvilliers Y, Ferri R, Fung C, Gozal D. National sleep foundation's sleep quality recommendations: first report. Sleep Health 2017;3:6-19.
28. Müller MJ, Kundermann B, Cabanel N. Eveningness and poor sleep quality independently contribute to self-reported depression severity in psychiatric inpatients with affective disorder. Nord J Psychiatry 2016;70:329-34

29. Müller MJ, Olschinski C, Kundermann B, Cabanel N. Sleep Duration of Inpatients With a Depressive Disorder: Associations With Age, Subjective Sleep Quality, and Cognitive Complaints. Arch Psychiatr Nurs 2017;31:77-82.

30. Pappa S, Ntella V, Giannakas T, Giannakoulis VG, Papoutsi E, Katsaounou P. Prevalence of depression, anxiety, and insomnia among healthcare workers during the COVID-19 pandemic: A systematic review and meta-analysis. Brain Behav Immun 2020;88:901-7. 